\title{
The Metaphysics of Mind and the Practical Science of the Law
}

\author{
SARAH A. SEO AND JOHN FABIAN WITT
}

In "Mind of a Moral Agent," Susanna Blumenthal elegantly limns the rise and partial fall of the common sense theory of moral responsibility in American law. ${ }^{1}$ As Blumenthal convincingly describes it, the problem for early American jurists was nothing less than to solve the paradox of determinism and free will. How can the law declare someone morally culpable unless we are free to choose our own ends?

After the Revolution, according to Blumenthal's account, American doctors and jurists turned to a sunny, Scottish Enlightenment theory of moral responsibility. In place of the tortured moral gymnastics of an older generation of Calvinist-influenced thinkers, men like Benjamin Rush and James Wilson adopted the Scots' idea of an innate moral faculty-a moral sensibility with which to distinguish right from wrong. ${ }^{2}$ The dilemma of responsibility seemed to have been solved. Human beings possessed the equipment with which to determine their fate, and if a person chose to pursue a morally wrong path, legal liability was her just desert.

The rest of Blumenthal's story traces the slow (and still incomplete) retreat of this theory under the accumulating weight of the nineteenth-century science of the mind. The Scottish understanding of the moral sense left one mystery unaddressed. If men are naturally endowed with a universal moral

1. Susanna Blumenthal, "The Mind of a Moral Agent: Scottish Common Sense and the Problem of Responsibility in Nineteenth-Century American Law," Law and History Review 26 (2008): 99-159.

2. On Wilson, see John Fabian Witt, Patriots and Cosmopolitans: Hidden Histories of American Law (Cambridge: Harvard University Press, 2007).

Sarah A. Seo is Law Clerk to the Honorable Denny Chin, United States District Court for the Southern District of New York, 2007-2008<as2607@columbia .edu>. John Fabian Witt is a professor of law and history at Columbia Law School $<$ jwitt@law.columbia.edu>. 
sensibility, how can we explain acts that depart from the path of morality? Nineteenth-century medical jurisprudence sought to bolster the idea of an innate moral sense. But as time went by, it instead threatened to undo the moral theory on which the law had come to rest. Though their conclusions were often unsatisfying - to them as to us, no doubt! - the alienists and lawyers of the nineteenth century bequeathed to us the legal theory of responsibility embedded in the law today, one that is halfway between a common sense moral theory of responsibility and a pragmatic surrender to the intractable dilemmas of free will and responsibility. Blumenthal's haunting final passages make clear just how unsatisfactory our resolution of the problem has been.

Yet for all the lingering moral resonances of the story, the main currents of American law seem again and again to have skirted the problem of moral agency instead of grappling with it. For prudential reasons, the constitutional law of the early republic adopted an approach to the moral sensibility of mankind that was at odds with the assumptions of the common sense theorists. In private law fields such as crime and tort, the jurists who struggled to accommodate the law to the extraordinary social transformations of the nineteenth century often tried to avoid the issue altogether.

The common sense moral theory of Francis Hutcheson and Thomas Reid was not the only theory of human moral propensities propounded in the late eighteenth and early nineteenth centuries. Ever since the early work of J. G. A. Pocock, Bernard Bailyn, and Gordon Wood, American historians have been closely attuned to the persistence of the dark, early modern view of the self that flowed alongside Enlightenment currents. ${ }^{3}$ Indeed, alongside the sanguine theories of Wilson and Rush existed a far more cynical view that owed much to the older moral skepticism of Calvin and even Machiavelli. This latter conception, reflected in Hamilton and Madison's theory in The Federalist that men are not angels, is among the most famous theories of human nature in American politics. ${ }^{4}$ American constitutional law, founded on a republican theory of man's innate tendencies toward sin and corruption, enshrined Hamilton and Madison's skepticism into the many checks, balances, and veto powers found in American political and legal institutions. Wilson and Madison may have agreed on

3. John Greville Agard Pocock, The Machiavellian Moment: Florentine Political Thought and the Atlantic Republican Tradition (Princeton: Princeton University Press, 1975); Bernard Bailyn, The Ideological Origins of the American Revolution (Cambridge: Harvard University Press, 1967); Gordon S. Wood, The Radicalism of the American Revolution (New York: Knopf, 1991).

4. See The Federalist Papers, ed. Clinton Rossiter (New York: New American Library, 1961). 
many things at the Constitutional Convention in the summer of 1787 , but the moral sense was not one of them. ${ }^{5}$

So what, then, do we make of the status of the Scottish common sense school in the early republic? At the very least, there were competitor theories that challenged its claim as the consensus view. The span of nineteenthcentury theorizing about the mind, therefore, must have stretched beyond the arc of common sense thought, though Blumenthal demonstrates that common sense thinking was surely important. Interestingly, nineteenthcentury lawyers seem to have had relatively little sense that the private law that Blumenthal describes - the law of contract, crime, tort, and willsrested on a theory of moral action at odds with the Madisonian theory underlying the Constitution. The theory of mind in the law of the early republic seems to have been as unruly and incoherent as it is today at the outset of the twenty-first century. ${ }^{6}$

Yet if one adopts a broad view, a remarkable fact appears: theorizing about the metaphysics of moral responsibility doesn't seem to have mattered very much. Take, for example, the criminal law. Some of the alienists of the nineteenth century were beginning to suggest that actors who were incapable of conforming to common sense dictates were unaccountable and, therefore, not punishable for their actions. But this quandary was in some ways increasingly academic. The birth of the prison and the discovery of the asylum changed the stakes of criminal adjudication in ways that transformed (and often discounted) the significance of the moral questions at issue. ${ }^{7}$ Imprisonment was an alternative to capital punishment, and institutionalizing the insane provided an alternative to imprisonment for those who could not be guilty according to the moral meaning of the word. ${ }^{8}$ Yet the effect of imprisonment and institutionalization was often more or less the same. In 1911, the New York State Bar Association recommended that should the jury return a special verdict of "guilty, but insane," the court "shall sentence such person to confinement in a state asylum for the criminal insane for such term as he would have had to serve in prison, but for the finding of insanity." At the time, at least four states and the U.S. territory Hawaii had such statutory provisions for the commitment

5. On Wilson and Madison, see Witt, Patriots and Cosmopolitans.

6. Compare Walter Johnson, "Inconsistency, Contradiction, and Complete Confusion: The Everyday Life of the Law of Slavery," Law and Social Inquiry 22 (1997): 405.

7. See Gerald Grob, The State and the Mentally Ill (Chapel Hill: University of North Carolina Press, 1966); Gerald Grob, Mental Institutions in America (New York: Free Press, 1973); David Rothman, The Discovery of the Asylum (Boston: Little, Brown, 1971).

8. Edwin R. Keedy, Chairman, "Insanity and Criminal Responsibility (Report of Committee B of the Institute)," Journal of the American Institute of Criminal Law and Criminology 92 (1911): 521, 531 . 
of defendants acquitted for crimes based on the insanity defense. ${ }^{9}$ Insane or morally responsible, the outcome was virtually identical.

Or consider the questions that arose in the law of torts, a body of law created when the industrial revolution and industrial accidents began to wreak havoc on the bodies of workers and passengers, among others. In torts, the question is not whether a defendant should be held criminally liable for her acts, but whether he should be required to pay compensation to the injured plaintiff. Yet the moral responsibility question rears its head once again. Is it just to hold a defendant accountable for an injury if the defendant had no moral control over the behavior that caused the injury?

This problem is one of the long-standing dilemmas of tort doctrine, one that is especially difficult in cases of insanity. In The Common Law, Oliver Wendell Holmes described the problem with reference to the insane thus:

There is no doubt that in many cases a man may be insane, and yet perfectly capable of taking the precautions, and of being influenced by the motives, which the circumstances demand. But if insanity of a pronounced type exists, manifestly incapacitating the sufferer from complying with the rule which he has broken, good sense would require it to be admitted as an excuse. ${ }^{10}$

In just the past few years, this passage has been front and center once more in a debate between leading torts scholars about the moral basis of tort liability. ${ }^{11}$ Is the standard articulated by Holmes objective (as many other passages in The Common Law seem to suggest), or is it subjective? The difference is important. An objective standard abandons the project of accounting for the moral responsibility of the defendant and asks whether the defendant lived up to a social standard or an average, without regard to whether it was culpable for the defendant not to have done so. The thorny problem of insanity in tort law would thus have provided Holmes an occasion to work through some of the deep problems involved in the idea of moral culpability.

But Holmes is not really discussing the moral responsibility problem at all in this passage. Rather, he is articulating a rule that will best allow people engaged in social life to cooperate and interact to their joint benefit. In just a few lines above the passage set out in the previous paragraph, Holmes tells us what he really thinks: "When a man has a distinct defect of such a nature that all can recognize it as making certain precautions impossible, he will not be held answerable for not taking them." $A$ "distinct defect" that "all can recognize." Here, Holmes is interested in a quite

9. The four states were Indiana, Nebraska, Rhode Island, and South Dakota.

10. See Oliver Wendell Holmes, The Common Law (Boston: Little, Brown, 1881), 108.

11. George Fletcher, "The Fault of Not Knowing," Theoretical Inquiries in Law 3 (2002): 265; Robert Rabin, "The Fault of Not Knowing, A Comment," Theoretical Inquiries in Law 4 (2003): 427. 
practical question far removed from the metaphysics of the mind that he debated on weekends with Henry James and Sir Frederick Pollock. The practical question is captured in the last sentence of his account of the liability of the insane: the behavior at issue is not negligent (and thus not liability producing) "if insanity of a pronounced type exists, manifestly incapacitating the sufferer from complying with the rule." Holmes's theory of liability for the insane simply asked which of the parties involved, the insane defendant or the plaintiff, was better positioned to reduce the risk arising out of their interaction. In the case of disabilities that announced themselves to others (distinct defects such as blindness, infancy, and a pronounced and manifest insanity), the plaintiff was in a better position to reduce the risk, and so properly bore that risk.

Much like Holmes, nineteenth-century courts worked out a solution that reflects a response to a set of pragmatic considerations and institutional changes rather than the philosophical and intellectual changes Blumenthal emphasizes. Instead of focusing on the structure of moral agency, nineteenthcentury judges determined negligence liability according to the information a party had regarding one's own or others' disability. In other words, judges often chose between the subjective and objective negligence standards based on a "notice principle," which essentially worked as a burden-shifting rule from the objective to the subjective standard when one party was on notice or was aware of another's disability. ${ }^{12}$ ("When a man has a distinct defect of such a nature that all can recognize it as making certain precautions impossible, he will not be held answerable for not taking them."'13) For instance, if a train conductor noticed that a pedestrian suffered from a mental illness that prevented exercise of requisite care when crossing the tracks, then it became the conductor's duty to take more care than the objective standard required to avoid a collision; and in the case of an accident, the pedestrian would be held to a subjective standard. ${ }^{14}$ Otherwise, if the conductor was not aware of the mental condition, then the prevailing objective standard still applied

12. Sarah A. Seo, "Negligence Standards, the Notice Principle, and Private Ordering in Early American Tort Law" (May 2007, unpublished manuscript, on file with author).

13. Holmes, Common Law, 109, n. 10 (emphasis added).

14. Compare McAdoo v. Richmond \& D.R. Co., 11 S.E. 316 (N.C. 1890) with Daily v. Richmond \& D.R. Co., 11 S.E. 320 (N.C. 1890). The facts in both railroad crossing cases, decided on the same day, are substantially the same, except that in Daily, the pedestrian was "an idiot." Though the North Carolina Supreme Court denied recovery to both plaintiffs, the rationale for its decisions was different in each case. McAdoo's claim failed because of the jury's subsequent finding of contributory negligence in failing to stop, look, and listen for approaching trains before crossing; whereas Daily's claim failed because there had been no evidence "tending to show that the engineer knew him when he saw him upon the track, or could ... have seen him, and had actual knowledge ... for the belief that, on account of some mental or physical infirmity, he could not assume that plaintiff would step off the track in time to escape injury." 
to both parties, regardless of whether it was impossible for the mentally ill pedestrian to meet that standard.

Attaching liability to information furthered a number of practical goals. To begin with, such an approach encouraged parties to account for observable disabilities in others and thus promoted a kind of informal private ordering, guiding parties toward an efficient allocation of the costs of taking extra precaution to avoid accidents. The notice principle, moreover, had a mitigating effect on the strict-liability-like effects of the objective standard for mentally unsound people. At the same time, by triggering a heightened duty only with notice, railroads, cities, and other corporate defendants were not required to adopt safety measures for their general operations at an inefficiently high level solely to accommodate those who could not meet the reasonable person standard. And perhaps most important, from the perspective of state court judges unable to keep abreast of the philosophical debates among Holmes and his friends, focusing the issue on notice allowed them to avoid the intractable questions of responsibility that arose in insanity cases. The sensibility and efficacy with which they approached these theoretically troublesome negligence cases show how the law of responsibility in tort has been just as concerned with pragmatic or social utility considerations as with the abstract metaphysics on which Blumenthal focuses.

In this short comment, we have focused on the legal fallout from just two of the myriad, extraordinary social transformations during the nineteenth century: the rise of institutions such as the prison and the asylum, on the one hand, and the industrial revolution's collateral consequences, on the other. It would be remarkable if these phenomena had not powerfully affected the law's practical science of moral responsibility, and they surely did.

Despite the weight of the philosophical questions on moral responsibility and human agency, it seems fair to say that judges gave much less thought to these knotty and insoluble questions than did the alienists who served as expert witnesses. This is not surprising, considering that the expert witnesses were in the business of promoting their own expertise.

The judges' role, in contrast, was to resolve cases. Though many, without a doubt, were mindful of the various theoretical issues of their day, theories often proved to be inconclusive guides to nineteenth-century judges who daily confronted the particular needs of the parties before them and of society at large. As the torts cases involving insanity indicate, judges often relied on practical solutions to the otherwise intractable questions of moral responsibility. 


\section{Scottish Common Sense and Nineteenth- Century American Law: A Critical Appraisal}

\section{JOHN MIKHAIL}

One overriding concern I have with Susanna Blumenthal's insightful and stimulating article, "The Mind of a Moral Agent: Scottish Common Sense and the Problem of Responsibility in Nineteenth-Century American Law," is whether there is anything sufficiently distinctive about Scottish Common Sense philosophy that justifies the role Blumenthal ascribes to it. In a representative passage, she writes:

Common Sense philosophy left would-be "moral managers" with a puzzle. If rational and moral faculties were innate and universal, what explained the great conflicts among men concerning matters of belief, manners, and morals ... leading some to commit acts that were ... patently irrational or downright evil? And to the extent that there was a common sense about the dictates of reason, propriety, and moral sense, why did some individuals act in defiance of them? $?^{2}$

These and similar questions that Blumenthal relies upon to frame and motivate her lucid analysis of the medical jurisprudence of the antebellum period are hardly unique to the philosophy of Reid, Beattie, Stewart, and Ferguson. Most classic British moralists would do just as well, including fellow Scots like Hutcheson, Hume, Smith, and Kames, along with prominent non-Scots like Shaftesbury, Clarke, Butler, and Price. Indeed, one could probably replace "Common Sense philosophy" in Blumenthal's

1. Susanna Blumenthal, "The Mind of a Moral Agent: Scottish Common Sense and the Problem of Responsibility in Nineteenth-Century American Law," Law and History Review 26 (2008): 99-159.

2. Ibid., 118.

John Mikhail is an associate professor of law at Georgetown University Law Center <mikhail@law.georgetown.edu>. He thanks Daniel Ernst for his comments on an earlier draft. 